\title{
Fluorescent Graphitic Carbon Nitride-Based Nanozymes with Peroxidase-like Activities for Ratiometric Biosensing
}

\author{
Xiaoyu Wang, ${ }^{1}$ Li Qin ${ }^{1}$, Minjie Lin ${ }^{2}$, Hang Xing ${ }^{2}$, and Hui Wei ${ }^{1,3,4 *}$ \\ ${ }^{1}$ Department of Biomedical Engineering, College of Engineering and Applied Sciences, Nanjing National Laboratory of \\ Microstructures, Jiangsu Key Laboratory of Artificial Functional Materials, Nanjing University, Nanjing, Jiangsu 210093, \\ China. \\ ${ }^{2}$ Institute of Chemical Biology and Nanomedicine, State Key Laboratory for Chemo/Bio Sensing and Chemometrics, \\ College of Chemistry and Chemical Engineering, Hunan University, Changsha, Hunan 410082, China. \\ ${ }^{3}$ State Key Laboratory of Analytical Chemistry for Life Science and State Key Laboratory of Coordination Chemistry, \\ School of Chemistry and Chemical Engineering, Nanjing University, Nanjing, Jiangsu 210023, China. \\ ${ }^{4}$ Key Laboratory of Analytical Chemistry for Biology and Medicine (Wuhan University), Ministry of Education, Wuhan \\ 430072, China.
}




\section{Table of contents}

Figure S1. TEM image of $\mathrm{C}_{3} \mathrm{~N}_{4}$.

Figure S2. Characterization of $\mathrm{C}_{3} \mathrm{~N}_{4}-\mathrm{Cu}$. (a) TEM image of $\mathrm{C}_{3} \mathrm{~N}_{4}-\mathrm{Cu}$. (b) PXRD pattern of $\mathrm{C}_{3} \mathrm{~N}_{4}-\mathrm{Cu}$. (c) FTIR spectrum of $\mathrm{C}_{3} \mathrm{~N}_{4}-\mathrm{Cu}$. (d) XPS spectrum of $\mathrm{Cu} 2 \mathrm{p}$ in $\mathrm{C}_{3} \mathrm{~N}_{4}-\mathrm{Cu}$.

Figure S3. XPS spectrum of $\mathrm{Ru} 3 p$ in $\mathrm{C}_{3} \mathrm{~N}_{4}-\mathrm{Ru}$.

Figure S4. Characterization of $\mathbf{C}_{3} \mathrm{~N}_{4}$-hemin. (a) TEM image of $\mathrm{C}_{3} \mathrm{~N}_{4}$-hemin. (b) PXRD pattern of $\mathrm{C}_{3} \mathrm{~N}_{4}$-hemin. (c) FTIR spectrum of the obtained $\mathrm{C}_{3} \mathrm{~N}_{4}$-hemin. (d) XPS spectrum of Fe $2 \mathrm{p}$ in $\mathrm{C}_{3} \mathrm{~N}_{4}$-hemin.

Figure S5. Peroxidase-like activity of $\mathbf{C}_{3} \mathbf{N}_{4}-\mathbf{R u}$ nanozymes. (a) Absorption spectra of different reaction systems of $2 \mathrm{mM}$ OPD, $10 \mu \mathrm{g} / \mathrm{mL}$ of $\mathrm{C}_{3} \mathrm{~N}_{4}-\mathrm{Ru}+2 \mathrm{mM}$ OPD, $20 \mathrm{mM} \mathrm{H}_{2} \mathrm{O}_{2}+2 \mathrm{mM}$ OPD, and $10 \mu \mathrm{g} / \mathrm{mL}$ of $\mathrm{C}_{3} \mathrm{~N}_{4}-\mathrm{Ru}+2 \mathrm{mM} \mathrm{OPD}+20$ $\mathrm{mM} \mathrm{H}_{2} \mathrm{O}_{2}$ after catalyzing oxidation in $\mathrm{pH} 4.5,0.2 \mathrm{M}$ acetate buffer at $37{ }^{\circ} \mathrm{C}$ for $5 \mathrm{~min}$. (b) Absorption spectra of $2 \mathrm{mM}$ OPD, $1 \mathrm{mM}$ TMB, and 1mM ABTS after catalyzing oxidation with $10 \mathrm{mM} \mathrm{H}_{2} \mathrm{O}_{2}$ in $\mathrm{pH} 4.5$ acetate buffer at $37{ }^{\circ} \mathrm{C}$ in the presence of $5 \mu \mathrm{g} / \mathrm{mL}$ of $\mathrm{C}_{3} \mathrm{~N}_{4}$-Ru for $5 \mathrm{~min}$. Inset: corresponding images showing the visual color changes of (I) OPD, (II) TMB, and (III) ABTS after the $\mathrm{C}_{3} \mathrm{~N}_{4}$-Ru catalyzed reaction. (c) Kinetic curves of $\mathrm{A}_{450}$ for monitoring the catalytic reation of $2 \mathrm{mM}$ OPD with various concentration of $\mathrm{C}_{3} \mathrm{~N}_{4}$ - Ru nanozymes in the presence of $10 \mathrm{mM} \mathrm{H}_{2} \mathrm{O}_{2}$. (d) Kinetic curves of $\mathrm{A}_{450}$ for monitoring the catalytic reation of $2 \mathrm{mM}$ OPD with various concentration of $\mathrm{H}_{2} \mathrm{O}_{2}$ in the presence of $5 \mu \mathrm{g} / \mathrm{mL}$ $\mathrm{C}_{3} \mathrm{~N}_{4}-\mathrm{Ru}$ nanozymes.

Figure S6. Fluorescence spectra of $\mathrm{C}_{3} \mathrm{~N}_{4}$-Ru nanosheets-based nanozymes in various reaction systems. Experiments were performed at $37{ }^{\circ} \mathrm{C}$ for $40 \mathrm{~min}$ in $\mathrm{pH} 4.5$ acetate buffer. $10 \mu \mathrm{g} / \mathrm{mL} \mathrm{C}_{3} \mathrm{~N}_{4}$ - $\mathrm{Ru}, 500 \mu \mathrm{M} \mathrm{H}_{2} \mathrm{O}_{2}$, and $2 \mathrm{mM}$ OPD were used in these reactions.

Figure S7. (a) Fluorescence spectra of $\mathrm{C}_{3} \mathrm{~N}_{4}-\mathrm{Cu}$ nanozyme in the presence of various concentrations of ATP. (b) Fluorescence spectra of $\mathrm{C}_{3} \mathrm{~N}_{4}-\mathrm{Cu}$ nanozyme in the presence of $250 \mu \mathrm{M}$ phosphates. (c) Ratiometric fluorescent responses $\left(\mathrm{F} / \mathrm{F}_{0}\right)$ of $\mathrm{C}_{3} \mathrm{~N}_{4}-\mathrm{Ru}, \mathrm{C}_{3} \mathrm{~N}_{4}-\mathrm{Cu}$, and $\mathrm{C}_{3} \mathrm{~N}_{4}$-hemin toward $10 \mu \mathrm{M}$ phosphates.

Figure S8. (a) Colorimetric response patterns $\left(\mathrm{A} / \mathrm{A}_{0}\right)$ of sensor arrays toward $10 \mu \mathrm{M}$ phosphates. Each error bar shows the standard deviation of five independent measurements. (b) $2 \mathrm{D}$ canonical score plot for the first two factors of the colorimetric response obtained against $10 \mu \mathrm{M}$ phosphates.

Figure S9. (a) Ratiometric fluorescence-response patterns $\left(\mathrm{F} / \mathrm{F}_{0}\right)$ of sensor arrays toward $1 \mu \mathrm{M}$ phosphates. Each error bar shows the standard deviation of five independent measurements. (b) 2D canonical score plot for the first two factors of the ratiometric fluorescence-response obtained against $1 \mu \mathrm{M}$ phosphates.

Figure S10. (a) Ratiometric fluorescence-response patterns $\left(\mathrm{F} / \mathrm{F}_{0}\right)$ of sensor arrays toward $5 \mu \mathrm{M}$ phosphates. Each error bar shows the standard deviation of five independent measurements. (b) 2D canonical score plot for the first two factors of the ratiometric fluorescence-response obtained against $5 \mu \mathrm{M}$ phosphates.

Figure S11. Ratiometric fluorescence-response patterns $\left(\mathrm{F} / \mathrm{F}_{0}\right)$ of sensor arrays towards various concentrations of ATP. Each error bar shows the standard deviation of five independent measurements.

Figure S12. Ratiometric fluorescence-response patterns $\left(\mathrm{F} / \mathrm{F}_{0}\right)$ of sensor arrays towards the mixtures of AMP and ATP at different molar ratios (total concentration at $2 \mu \mathrm{M}$ ). Each error bar shows the standard deviation of five independent measurements.

Figure S13. Ratiometric fluorescence-response patterns $\left(\mathrm{F} / \mathrm{F}_{0}\right)$ of sensor arrays towards $5 \mu \mathrm{M}$ of phosphates in the presence of $0.1 \%$ FBS. Each error bar shows the standard deviation of five independent measurements.

Figure S14. Ratiometric fluorescence-response patterns $\left(\mathrm{F} / \mathrm{F}_{0}\right)$ of sensor arrays towards 20 blind samples.

Table S1. Comparison of the current sensing system with reported methods for $\mathrm{H}_{2} \mathrm{O}_{2}$ detection.

Table S2. Identification of 20 blind samples. 


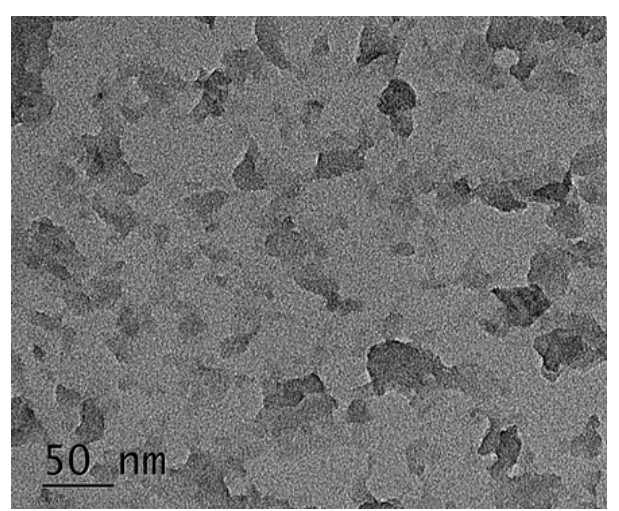

Figure S1. TEM image of $\mathrm{C}_{3} \mathrm{~N}_{4}$. 
(a)

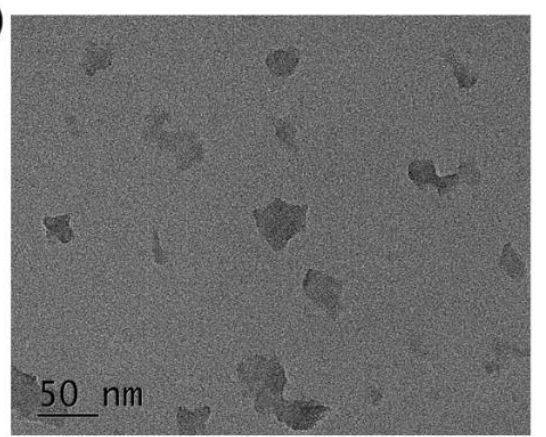

(c)

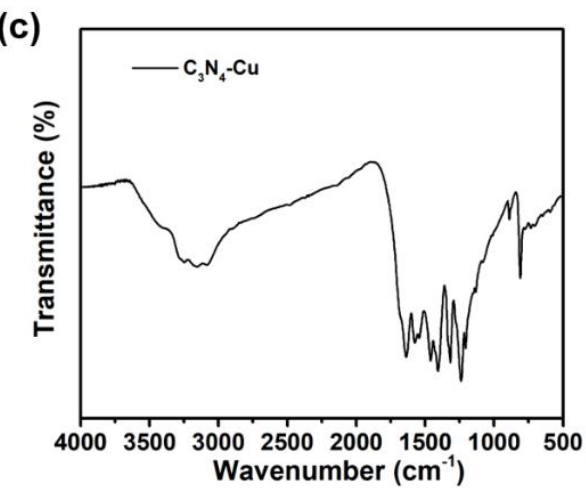

(b)

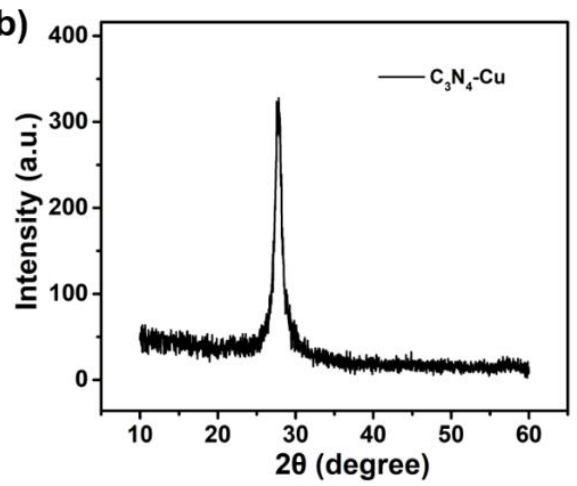

(d)

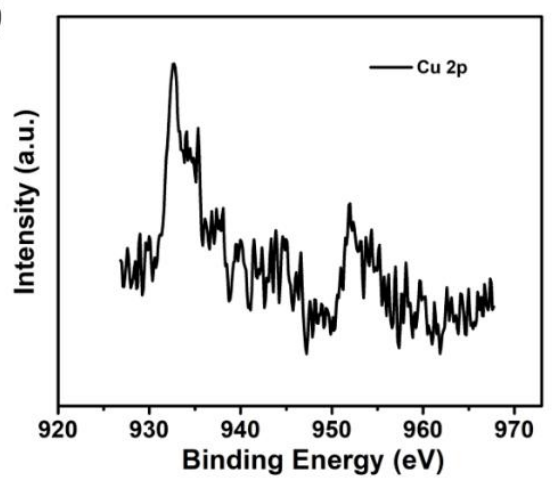

Figure S2. Characterization of $\mathrm{C}_{3} \mathrm{~N}_{4}-\mathrm{Cu}$. (a) TEM image of $\mathrm{C}_{3} \mathrm{~N}_{4}$-Cu. (b) PXRD pattern of $\mathrm{C}_{3} \mathrm{~N}_{4}-\mathrm{Cu}$. (c) FTIR spectrum of $\mathrm{C}_{3} \mathrm{~N}_{4}-\mathrm{Cu}$. (d) XPS spectrum of $\mathrm{Cu} 2 \mathrm{p}$ in $\mathrm{C}_{3} \mathrm{~N}_{4}-\mathrm{Cu}$.

Figure S2d exhibited the high-resolution XPS spectrum of $\mathrm{Cu} 2 \mathrm{p}$ in $\mathrm{C}_{3} \mathrm{~N}_{4}-\mathrm{Cu}$. Two peaks for $\mathrm{Cu} 2 \mathrm{p}_{3 / 2}$ and $\mathrm{Cu} 2 \mathrm{p}_{1 / 2}$ were located at 932.6 and $952.3 \mathrm{eV}$, where were typical values for $\mathrm{Cu}^{+}{ }^{1}$ 


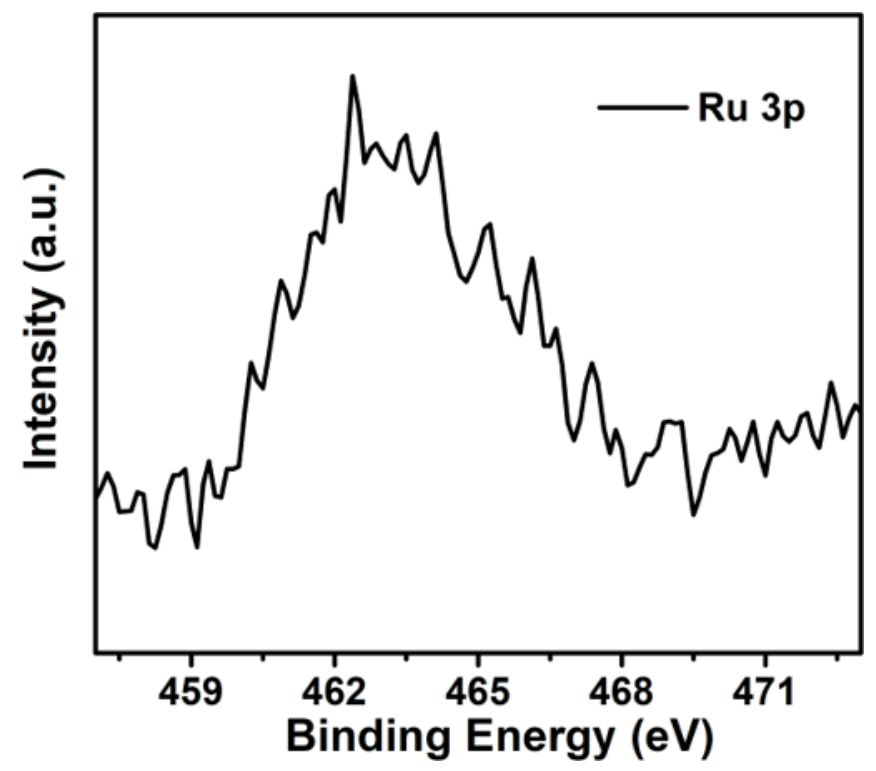

Figure S3. XPS spectrum of $\mathrm{Ru} 3 \mathrm{p}$ in $\mathrm{C}_{3} \mathrm{~N}_{4}-\mathrm{Ru}$.

Figure $\mathrm{S} 3$ exhibited the XPS spectrum of $\mathrm{Ru} 3 \mathrm{p}_{3 / 2}$ in $\mathrm{C}_{3} \mathrm{~N}_{4}-\mathrm{Ru}$. The peak for $\mathrm{Ru} 3 \mathrm{p}_{3 / 2}$ was located at about $462.5 \mathrm{eV}$, where was consistent with the presence of $\mathrm{Ru}^{2+}{ }^{2}$ 
(a)

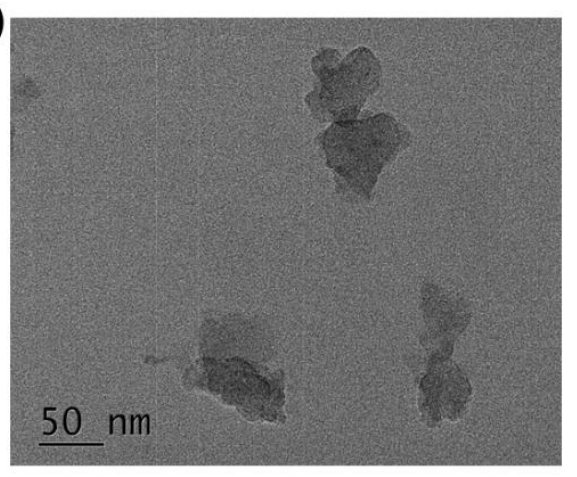

(c)

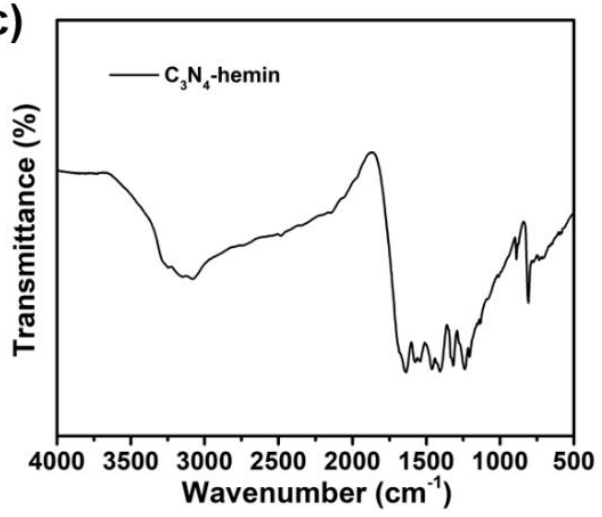

(b)

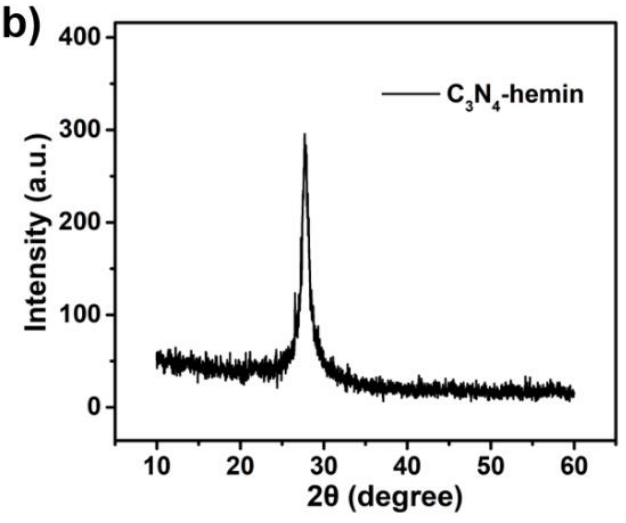

(d)

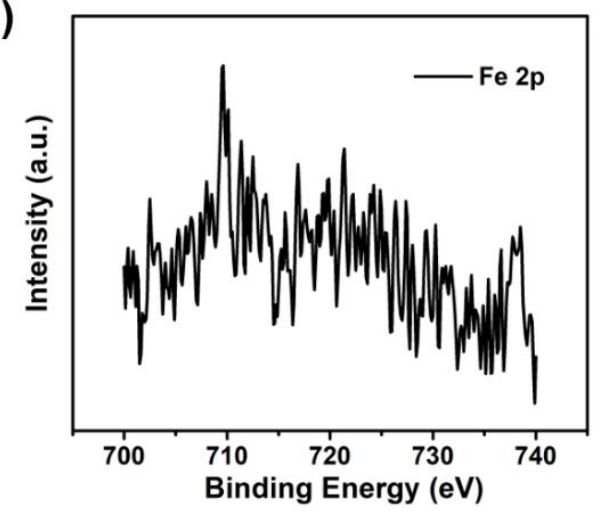

Figure S4. Characterization of $\mathrm{C}_{3} \mathrm{~N}_{4}$-hemin. (a) TEM image of $\mathrm{C}_{3} \mathrm{~N}_{4}$-hemin. (b) PXRD pattern of $\mathrm{C}_{3} \mathrm{~N}_{4}$-hemin. (c) FTIR spectrum of the obtained $\mathrm{C}_{3} \mathrm{~N}_{4}$-hemin. (d) XPS spectrum of Fe 2p in $\mathrm{C}_{3} \mathrm{~N}_{4}$-hemin.

As shown in Figure $\mathrm{S} 4 \mathrm{a}$, the $\mathrm{C}_{3} \mathrm{~N}_{4}$-hemin retained the original sheet morphology of $\mathrm{C}_{3} \mathrm{~N}_{4}$. PXRD exhibited the characteristic diffraction peak of the $\mathrm{C}_{3} \mathrm{~N}_{4}(002)$ plane at $27.2^{\circ}$, demonstrating the $\mathrm{C}_{3} \mathrm{~N}_{4}$-hemin possessed the same structure as $\mathrm{C}_{3} \mathrm{~N}_{4}$ (Figure $\mathrm{S} 4 \mathrm{~b}$ ). FTIR suggested that $\mathrm{C}_{3} \mathrm{~N}_{4}$-hemin preserved the chemical structure of $\mathrm{C}_{3} \mathrm{~N}_{4}$ (Figure $\mathrm{S} 4 \mathrm{c}$ ). Figure $4 \mathrm{~d}$ exhibited the high-resolution XPS spectrum of $\mathrm{Fe} 2 \mathrm{p}$ in $\mathrm{C}_{3} \mathrm{~N}_{4}$-hemin, demonstrating the successful conjugation of hemin with $\mathrm{C}_{3} \mathrm{~N}_{4}$. 

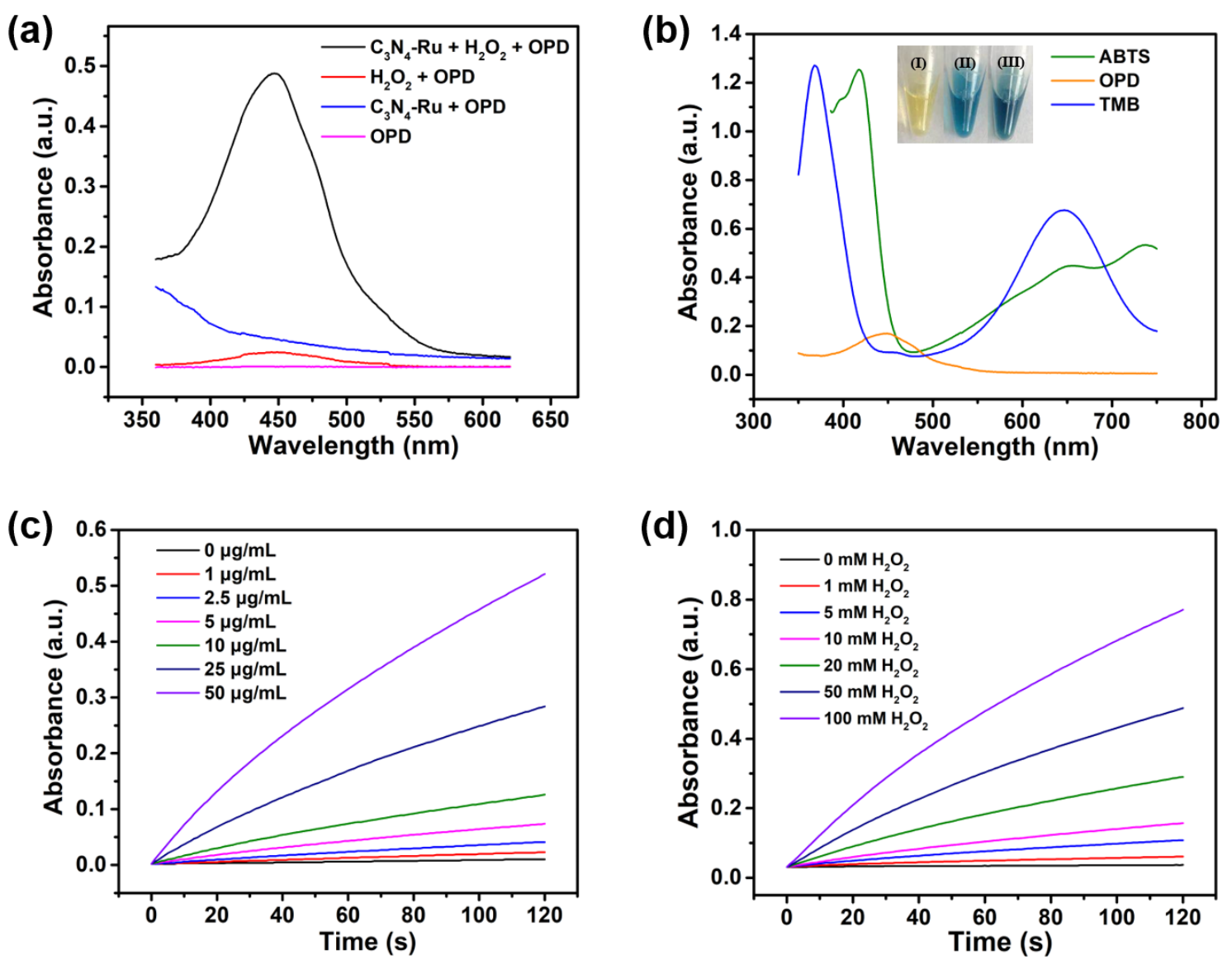

Figure S5. Peroxidase-like activity of $\mathbf{C}_{3} \mathbf{N}_{4}-$ Ru nanozymes. (a) Absorption spectra of different reaction systems of $2 \mathrm{mM}$ OPD, $10 \mu \mathrm{g} / \mathrm{mL}$ of $\mathrm{C}_{3} \mathrm{~N}_{4}-\mathrm{Ru}+2 \mathrm{mM}$ OPD, $20 \mathrm{mM} \mathrm{H}_{2} \mathrm{O}_{2}+2 \mathrm{mM}$ OPD, and $10 \mu \mathrm{g} / \mathrm{mL}$ of $\mathrm{C}_{3} \mathrm{~N}_{4}-\mathrm{Ru}+2 \mathrm{mM}$ OPD +20 $\mathrm{mM} \mathrm{H} \mathrm{H}_{2} \mathrm{O}_{2}$ after catalyzing oxidation in $\mathrm{pH} 4.5,0.2 \mathrm{M}$ acetate buffer at $37{ }^{\circ} \mathrm{C}$ for $5 \mathrm{~min}$. (b) Absorption spectra of $2 \mathrm{mM}$ OPD, $1 \mathrm{mM} \mathrm{TMB}$, and $1 \mathrm{mM}$ ABTS after catalyzing oxidation with $10 \mathrm{mM} \mathrm{H}_{2} \mathrm{O}_{2}$ in pH 4.5 acetate buffer at $37{ }^{\circ} \mathrm{C}$ in the presence of $5 \mu \mathrm{g} / \mathrm{mL}$ of $\mathrm{C}_{3} \mathrm{~N}_{4}$-Ru for $5 \mathrm{~min}$. Inset: corresponding images showing the visual color changes of (I) OPD, (II) TMB, and (III) ABTS after the $\mathrm{C}_{3} \mathrm{~N}_{4}-\mathrm{Ru}$ catalyzed reaction. (c) Kinetic curves of $\mathrm{A}_{450}$ for monitoring the catalytic reation of $2 \mathrm{mM}$ OPD with various concentration of $\mathrm{C}_{3} \mathrm{~N}_{4}-\mathrm{Ru}$ nanozymes in the presence of $10 \mathrm{mM} \mathrm{H}_{2} \mathrm{O}_{2}$. (d) Kinetic curves of $\mathrm{A}_{450}$ for monitoring the catalytic reation of $2 \mathrm{mM}$ OPD with various concentration of $\mathrm{H}_{2} \mathrm{O}_{2}$ in the presence of $5 \mu \mathrm{g} / \mathrm{mL}$ $\mathrm{C}_{3} \mathrm{~N}_{4}$ - $\mathrm{Ru}$ nanozymes. 


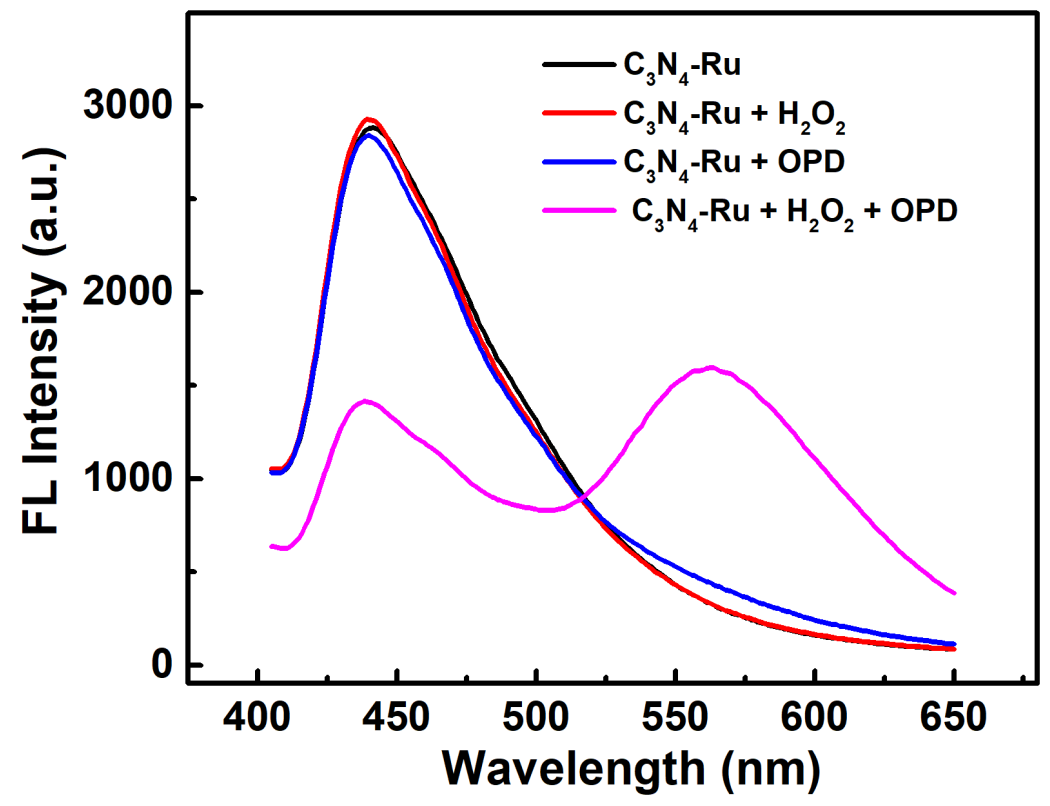

Figure S6. Fluorescence spectra of $\mathrm{C}_{3} \mathrm{~N}_{4}$-Ru nanosheets-based nanozymes in various reaction systems. Experiments were performed at $37^{\circ} \mathrm{C}$ for $40 \mathrm{~min}$ in $\mathrm{pH} 4.5$ acetate buffer. $10 \mu \mathrm{g} / \mathrm{mL} \mathrm{C}_{3} \mathrm{~N}_{4}-\mathrm{Ru}, 500 \mu \mathrm{M} \mathrm{H}_{2} \mathrm{O}_{2}$, and $2 \mathrm{mM}$ OPD were used in these reactions. 
(a)

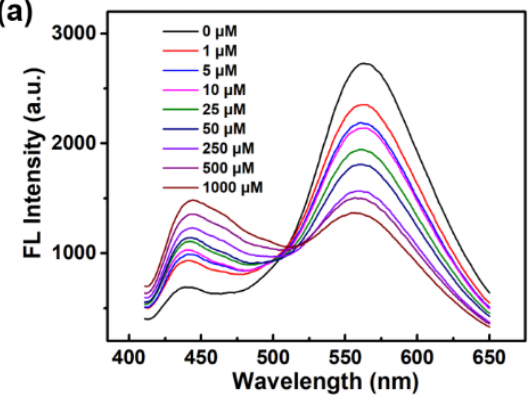

(b)

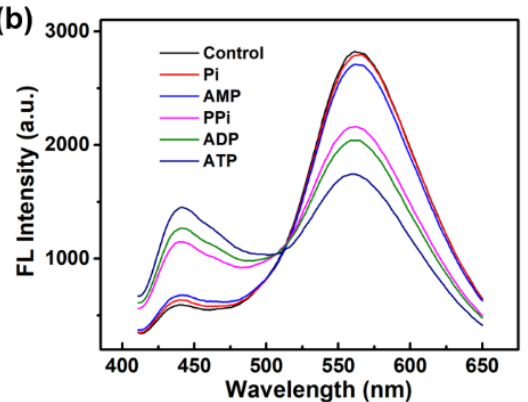

(c)

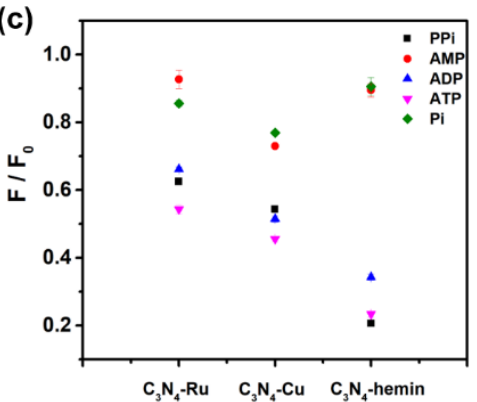

Figure S7. (a) Fluorescence spectra of $\mathrm{C}_{3} \mathrm{~N}_{4}-\mathrm{Cu}$ nanozyme in the presence of various concentrations of ATP. (b) Fluorescence spectra of $\mathrm{C}_{3} \mathrm{~N}_{4}-\mathrm{Cu}$ nanozyme in the presence of $250 \mu \mathrm{M}$ phosphates. (c) Ratiometric fluorescent responses $\left(\mathrm{F} / \mathrm{F}_{0}\right)$ of $\mathrm{C}_{3} \mathrm{~N}_{4}-\mathrm{Ru}, \mathrm{C}_{3} \mathrm{~N}_{4}-\mathrm{Cu}$, and $\mathrm{C}_{3} \mathrm{~N}_{4}$-hemin toward $10 \mu \mathrm{M}$ phosphates. Each error bar exhibits the standard deviation of five independent measurements. 
(a)

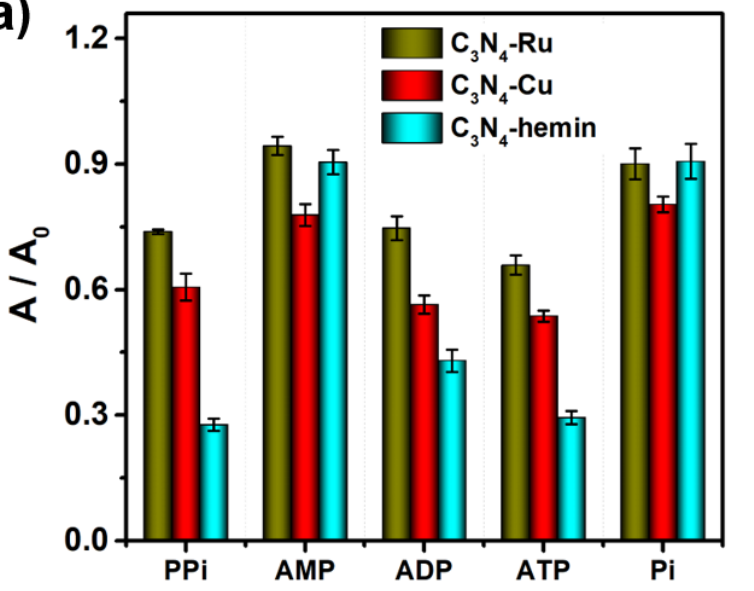

(b)

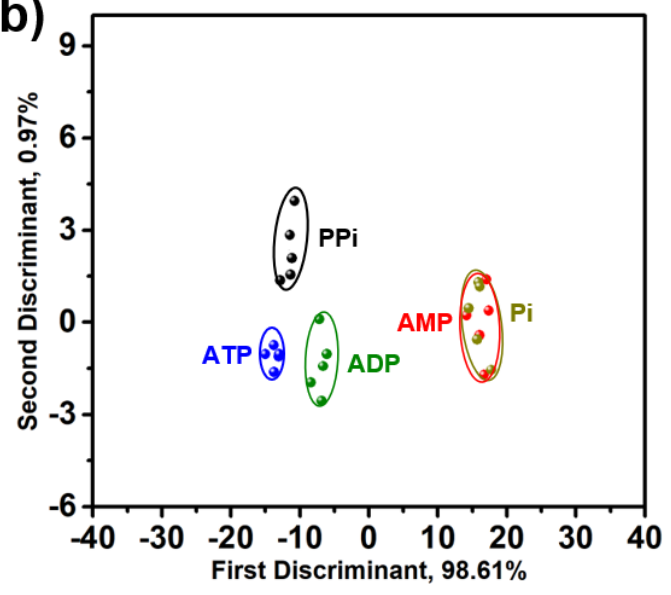

Figure S8. (a) Colorimetric response patterns $\left(\mathrm{A} / \mathrm{A}_{0}\right)$ of sensor arrays toward $10 \mu \mathrm{M}$ phosphates. Each error bar shows the standard deviation of five independent measurements. (b) 2D canonical score plot for the first two factors of the colorimetric response obtained against $10 \mu \mathrm{M}$ phosphates. 
(a)

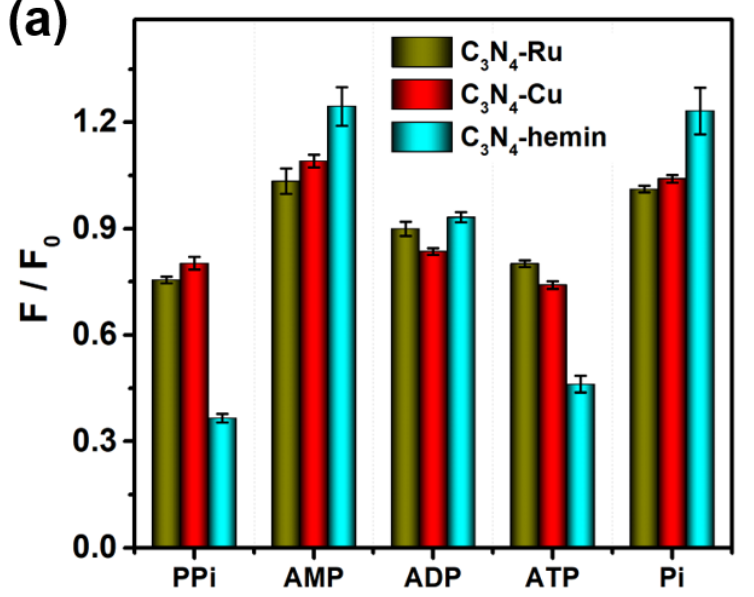

(b)

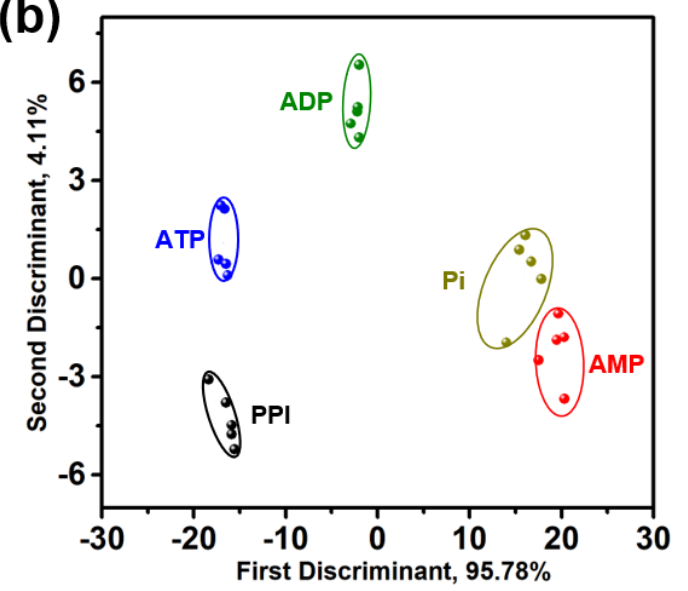

Figure S9. (a) Ratiometric fluorescence-response patterns $\left(\mathrm{F} / \mathrm{F}_{0}\right)$ of sensor arrays toward $1 \mu \mathrm{M}$ phosphates. Each error bar shows the standard deviation of five independent measurements. (b) 2D canonical score plot for the first two factors of the ratiometric fluorescence-response obtained against $1 \mu \mathrm{M}$ phosphates. 
(a)

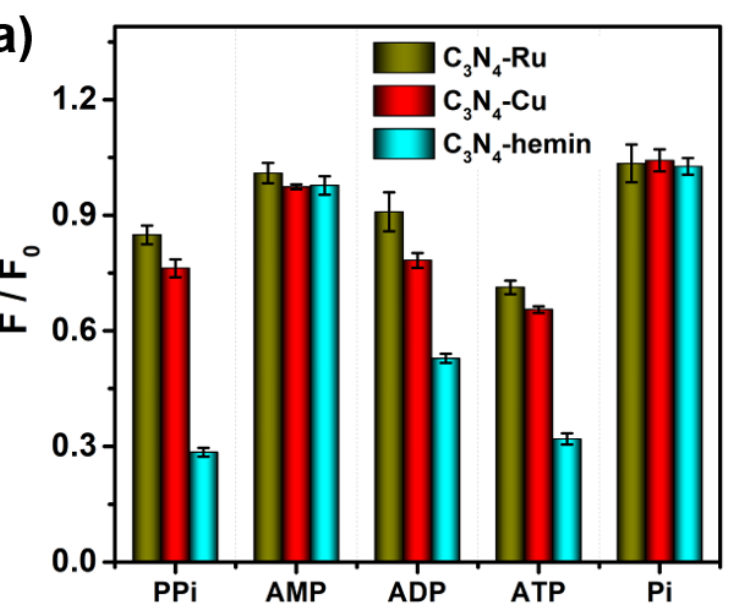

(b)

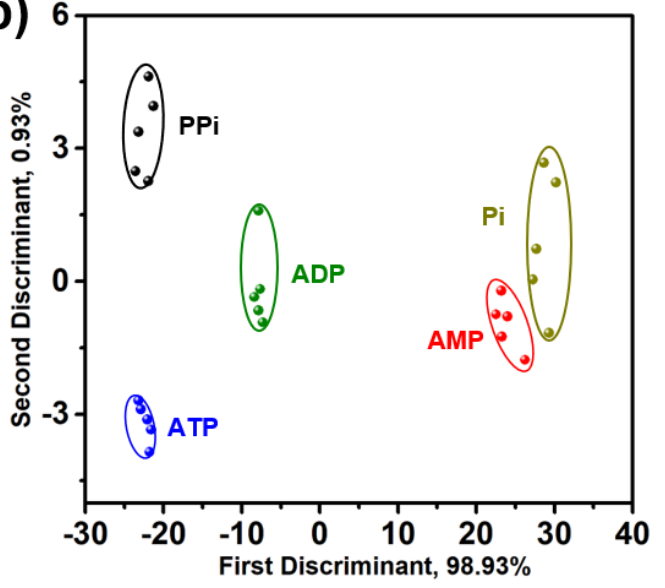

Figure S10. (a) Ratiometric fluorescence-response patterns $\left(\mathrm{F} / \mathrm{F}_{0}\right)$ of sensor arrays toward $5 \mu \mathrm{M}$ phosphates. Each error bar shows the standard deviation of five independent measurements. (b) 2D canonical score plot for the first two factors of the ratiometric fluorescence-response obtained against $5 \mu \mathrm{M}$ phosphates. 


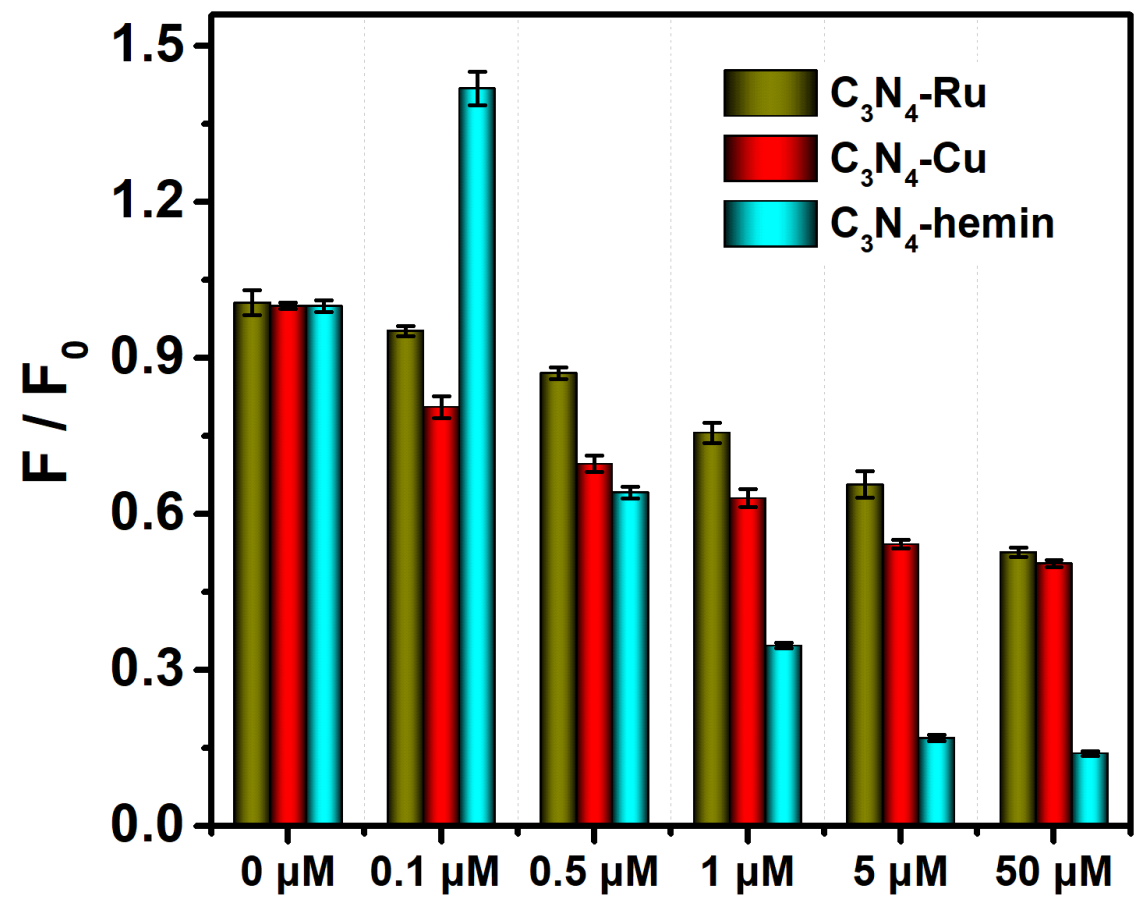

Figure S11. Ratiometric fluorescence-response patterns $\left(\mathrm{F} / \mathrm{F}_{0}\right)$ of sensor arrays towards various concentrations of ATP. Each error bar shows the standard deviation of five independent measurements. 


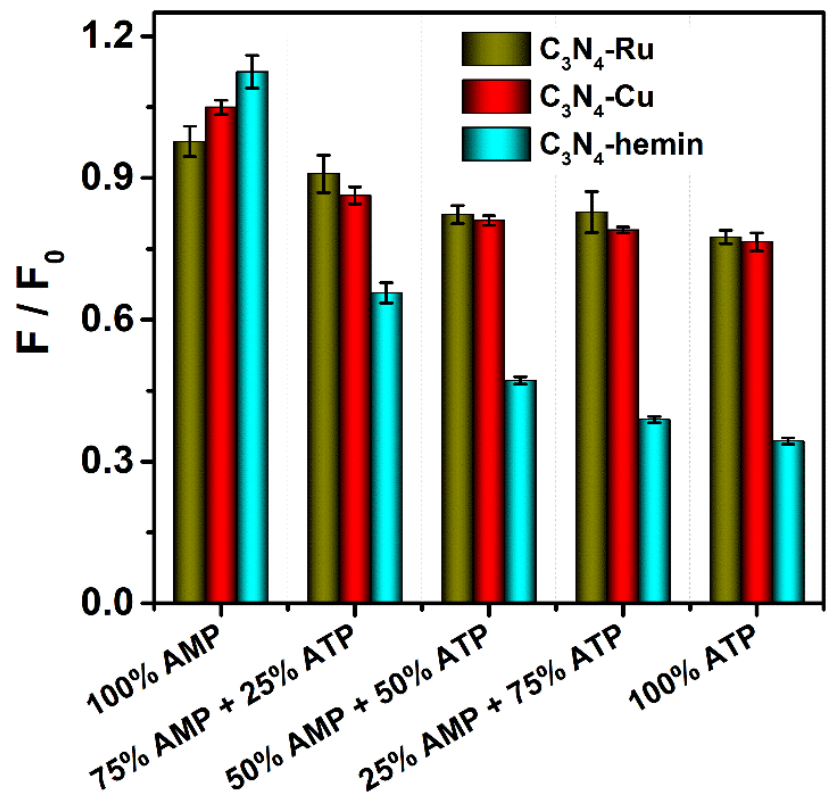

Figure S12. Ratiometric fluorescence-response patterns $\left(\mathrm{F} / \mathrm{F}_{0}\right)$ of sensor arrays towards the mixtures of AMP and ATP at different molar ratios (total concentration at $2 \mu \mathrm{M}$ ). Each error bar shows the standard deviation of five independent measurements. 


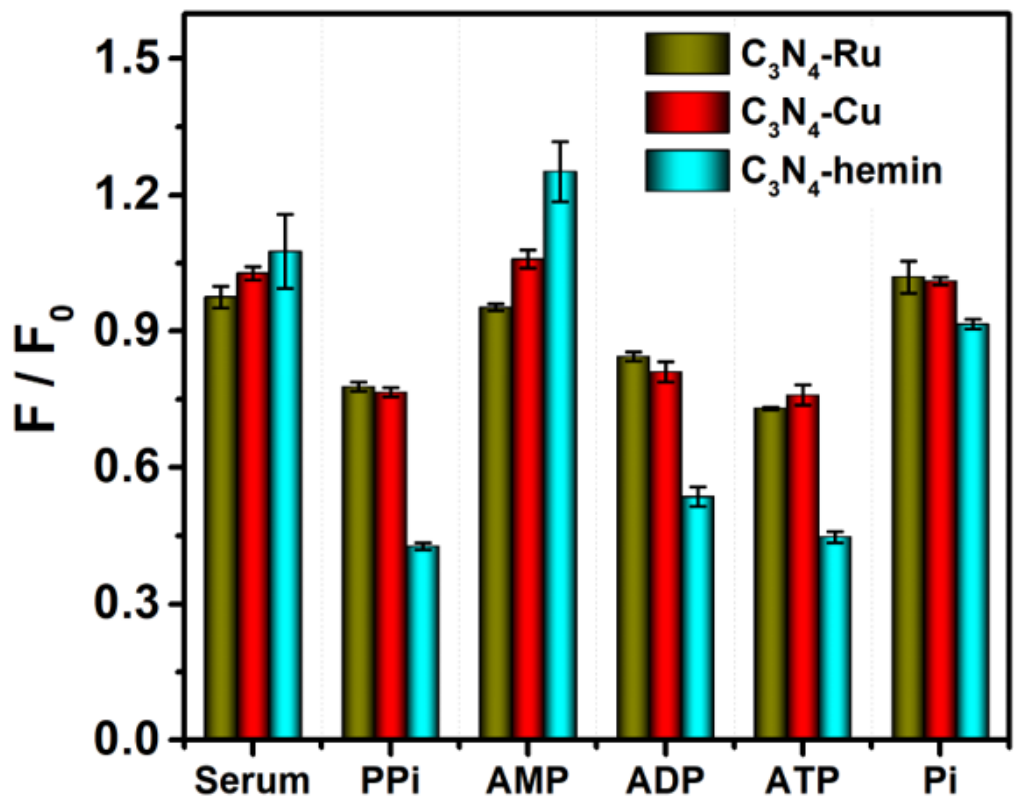

Figure S13. Ratiometric fluorescence-response patterns $\left(\mathrm{F} / \mathrm{F}_{0}\right)$ of sensor arrays towards $5 \mu \mathrm{M}$ of phosphates in the presence of $0.1 \%$ FBS. Each error bar shows the standard deviation of five independent measurements. 


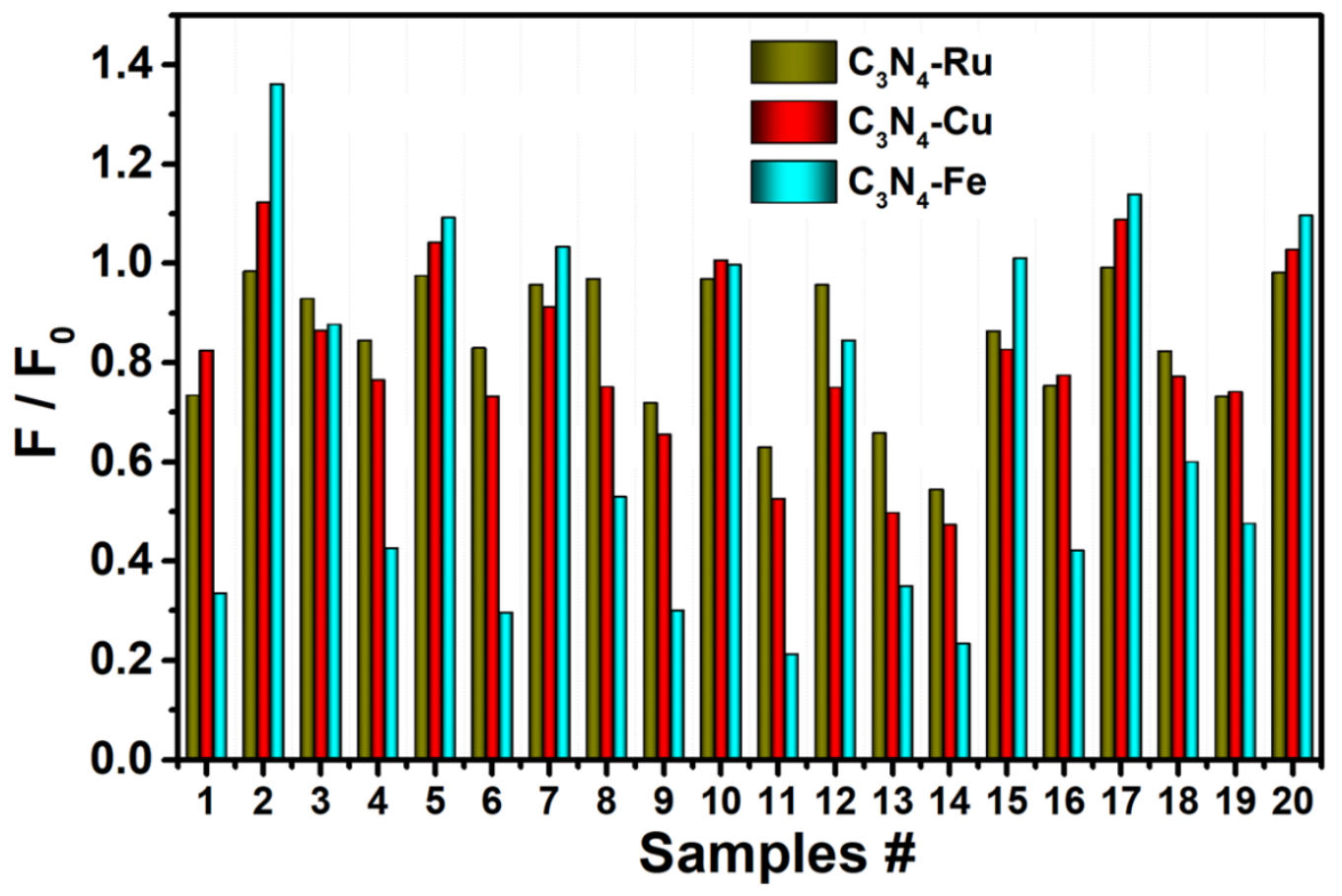

Figure S14. Ratiometric fluorescence-response patterns $\left(\mathrm{F} / \mathrm{F}_{0}\right)$ of sensor arrays towards 20 blind samples. 
Table S1. Comparison of the current sensing system with reported methods for $\mathrm{H}_{2} \mathrm{O}_{2}$ detection.

\begin{tabular}{|c|c|c|c|c|c|}
\hline Nanozymes & Methods & Detection limit & Linear range & Substrate & Ref. \\
\hline $\begin{array}{c}\mathrm{Au} @ \mathrm{TiO}_{2} \text { yolk-shell } \\
\text { nanostructure }\end{array}$ & Colorimetric & $4.0 \mu \mathrm{M}$ & $5-100 \mu \mathrm{M}$ & TMB & 3 \\
\hline $\begin{array}{l}\text { FePt-Au ternary } \\
\text { metallic NPs }\end{array}$ & Colorimetric & $12.33 \mu \mathrm{M}$ & $20-700 \mu \mathrm{M}$ & TMB & 4 \\
\hline $\begin{array}{l}\text { Hybridized Pt/cube- } \\
\mathrm{CeO}_{2} \text { nanocomposites }\end{array}$ & Colorimetric & $10.7 \mu \mathrm{M}$ & $0-100 \mu \mathrm{M}$ & TMB & 5 \\
\hline $\mathrm{LaNiO}_{3}$ cubes & Colorimetric & $2 \mu \mathrm{M}$ & $\begin{array}{c}0-30 \mu \mathrm{M} \text { and } \\
40-500 \mu \mathrm{M}\end{array}$ & TMB & 6 \\
\hline $\mathrm{MoS}_{2}$ nanoflakes & Colorimetric & $4.103 \mu \mathrm{M}$ & $0-300 \mu \mathrm{M}$ & $\mathrm{TMB}$ & 7 \\
\hline $\begin{array}{c}\mathrm{NiO} \text { nanoparticles } \\
\text { modified with } \mathrm{H}_{2} \mathrm{TCPP}\end{array}$ & Colorimetric & $8 \mu \mathrm{M}$ & $20-100 \mu \mathrm{M}$ & TMB & 8 \\
\hline $\mathrm{C}_{3} \mathrm{~N}_{4}-\mathrm{Ru}$ & Fluorometric & $4.2 \mu \mathrm{M}$ & $10-1000 \mu \mathrm{M}$ & OPD & $\begin{array}{l}\text { This } \\
\text { work }\end{array}$ \\
\hline
\end{tabular}

Ref., Reference

$\mathrm{H}_{2}$ TCPP, 5,10,15,20-tetrakis(4-carboxyl phenyl)-porphyrin

TMB, 3,3',5,5'-tetramethylbenzidine

OPD, $o$-phenylenediamine 
Table S2. Identification of 20 blind samples.

\begin{tabular}{ccccccc}
\hline No. & Concentration & \multicolumn{3}{c}{ Source Data } & Identification & Verification \\
\hline $\mathbf{1}$ & $1 \mu \mathrm{M}$ & 0.7343 & 0.8242 & 0.3352 & PPi & PPi \\
$\mathbf{2}$ & $1 \mu \mathrm{M}$ & 0.9838 & 1.1224 & 1.3606 & AMP & AMP \\
$\mathbf{3}$ & $1 \mu \mathrm{M}$ & 0.9284 & 0.8641 & 0.8768 & ADP & ADP \\
$\mathbf{4}$ & $1 \mu \mathrm{M}$ & 0.8443 & 0.7651 & 0.4264 & ATP & ATP \\
$\mathbf{5}$ & $1 \mu \mathrm{M}$ & 0.9744 & 1.0419 & 1.0921 & Pi & Pi \\
$\mathbf{6}$ & $5 \mu \mathrm{M}$ & 0.8292 & 0.7314 & 0.2962 & PPi & PPi \\
$\mathbf{7}$ & $5 \mu \mathrm{M}$ & 0.9568 & 0.9119 & 1.0329 & AMP & AMP \\
$\mathbf{8}$ & $5 \mu \mathrm{M}$ & 0.9686 & 0.7509 & 0.5296 & ADP & ADP \\
$\mathbf{9}$ & $5 \mu \mathrm{M}$ & 0.7187 & 0.6553 & 0.3007 & ATP & ATP \\
$\mathbf{1 0}$ & $5 \mu \mathrm{M}$ & 0.9683 & 1.0063 & 0.9971 & Pi & Pi \\
$\mathbf{1 1}$ & $10 \mu \mathrm{M}$ & 0.6290 & 0.5259 & 0.2126 & PPi & PPi \\
$\mathbf{1 2}$ & $10 \mu \mathrm{M}$ & 0.9564 & 0.7499 & 0.8448 & AMP & AMP \\
$\mathbf{1 3}$ & $10 \mu \mathrm{M}$ & 0.6581 & 0.4972 & 0.3497 & ADP & ADP \\
$\mathbf{1 4}$ & $10 \mu \mathrm{M}$ & 0.5440 & 0.4734 & 0.2341 & ATP & ATP \\
$\mathbf{1 5}$ & $10 \mu \mathrm{M}$ & 0.8634 & 0.8260 & 1.0107 & Pi & Pi \\
$\mathbf{1 6}$ & $10 \mu \mathrm{M}$ in Serum & 0.7531 & 0.7744 & 0.4212 & PPi & PPi \\
$\mathbf{1 7}$ & $10 \mu \mathrm{M}$ in Serum & 0.9912 & 1.0877 & 1.1384 & AMP & AMP \\
$\mathbf{1 8}$ & $10 \mu \mathrm{M}$ in Serum & 0.8228 & 0.7718 & 0.5994 & ADP & ADP \\
$\mathbf{1 9}$ & $10 \mu \mathrm{M}$ in Serum & 0.7316 & 0.7411 & 0.4755 & ATP & ATP \\
$\mathbf{2 0}$ & $10 \mu \mathrm{M}$ in Serum & 0.9815 & 1.0275 & 1.0964 & Serum & Pi \\
\hline & & & & & & \\
\hline
\end{tabular}

The samples in red were mis-identified. 


\section{References}

(1) Ling, P.; Zhang, Q.; Cao, T.; Gao, F. Versatile Three-Dimensional Porous $\mathrm{Cu} @ \mathrm{Cu}_{2} \mathrm{O}$ Aerogel Networks as Electrocatalysts and Mimicking Peroxidases. Angew. Chem., Int. Ed. 2018, 57, 6819-6824.

(2) Kumar, A.; Chhatwal, M.; Cristaldi, D. A.; Awasthi, S. K.; Gupta, R. D.; Gulino, A. Chromogenic Homo-Dinuclear Ruthenium(II) Monolayer as a Tunable Molecular Memory Module for Multibit Information Storage. J. Phys. Chem. C 2015, 119, 5138-5145.

(3) Peng, X.; Wan, G.; Wu, L.; Zeng, M.; Lin, S.; Wang, G. Peroxidase-like activity of Au@ $\mathrm{TiO}_{2}$ yolk-shell nanostructure and its application for colorimetric detection of $\mathrm{H}_{2} \mathrm{O}_{2}$ and glucose. Sens. Actuators, B, 2018, 257, 166-177.

(4) Ding, Y.; Yang, B.; Liu, H.; Liu, Z.; Zhang, X.; Zheng, X.; Liu, Q. FePt-Au ternary metallic nanoparticles with the enhanced peroxidase-like activity for ultrafast colorimetric detection of $\mathrm{H}_{2} \mathrm{O}_{2}$. Sens. Actuators, B, 2018, 259, 775-783.

(5) Li, Z.; Yang, X.; Yang, Y.; Tan, Y.; He, Y.; Liu, M.; Liu, X.; Yuan, Q. Peroxidase-Mimicking Nanozyme with Enhanced Activity and High Stability Based on Metal-Support Interactions. Chem.-Eur. J. 2018, 24, 409-415.

(6) Wang, X.; Cao, W.; Qin, L.; Lin, T.; Chen, W.; Lin, S.; Yao, J.; Zhao, X.; Zhou, M.; Hang, C.; Wei, H. Boosting the Peroxidase-Like Activity of Nanostructured Nickel by Inducing Its 3+ Oxidation State in $\mathrm{LaNiO}_{3}$ Perovskite and Its Application for Biomedical Assays. Theranostics 2017, 7, 2277-2286.

(7) Yu, J.; Ma, D.; Mei, L.; Gao, Q.; Yin, W.; Zhang, X.; Yan, L.; Gu, Z.; Ma, X.; Zhao, Y. Peroxidase-like activity of MoS nanoflakes with different modifications and their application for $\mathrm{H}_{2} \mathrm{O}_{2}$ and glucose detection. J. Mater. Chem. B 2018, 6, 487-498.

(8) Liu, Q.; Yang, Y.; Li, H.; Zhu, R.; Shao, Q.; Yang, S.; Xu, J. NiO nanoparticles modified with 5,10,15,20-tetrakis(4carboxyl pheyl)-porphyrin: Promising peroxidase mimetics for $\mathrm{H}_{2} \mathrm{O}_{2}$ and glucose detection. Biosens. Bioelectron. 2015, 64, 147-153. 